\title{
ELECTRIC CABLES AND FIRE RISKS
}

$\mathrm{M}^{\mathrm{R}}$ R. S. W. MELSOM, of the Cable Makers' Association, read a paper on March 13 on recent developments and investigations on electric cables and fire risks, befors the Transmission Section of the Institution of Electrical Engineers.

During the last four years there has been general concentration on the problem of fire risks in electrical installations and on the precautions necessary to eliminate them. These problems, which apply to ships, power stations and mines, are probably mostly due to the immense spread of the use of electrical energy and the enormously increased size of the power units and of the distribution units and the distribution systems. As a result of the various inquiries that have been held, the encouraging news has emerged that nowadays the fire risk due to faulty cables is exceedingly small, so small, in fact, that it may almost be ignored, and that, as regards cables, the real precautions to be taken are in respect of the spread of extraneous fire along the cable.

So far as ships are concerned, shipping records justly direct attention to the excellent record of British shipping in this respect. Regarding power stations, the report of the Electricity Commissioners does not ask for any special protection from fires arising within cables, and as for mines, all the evidence of fires in mines has exonerated cables. However satisfactory the general volume of proof may be, it will be obvious that the cable-making industry was bound to make all possible investigations and, in particular, to help in the solution of the problem of resisting the spread of an extraneous fire along a cable run.

The author said that a great deal of work has recently been done on the fireproofing of mains cables in power stations, generally with the view of protecting them from breakdown due to adjacent cables, more particularly in the manholes which are part of the large duct systems prevalent in the United States. It was not until 1937 that the subject was given serious consideration in Great Britain. The committee set up by the Electricity Commissioners as a result of painful experience worked energetically at the problem, and we are deeply indebted to this committee for $i^{*} \mathrm{~s}$ clarification of the problem and for the resultant proper provision for protection against fire.

It may be assumed from the published recommendations of the Commission that, so far as cables are concerned, the main problems to be faced arise from extraneous fires mainly due to flowing burning oil in a station or a substation. The recommendations of the Commissioners were made after full consultation with the industry, and with them the cable-makers are in full agreement.

It may be useful to discuss the manner of giving effect to these recommendations, and the effect that the protection may have on the performance of the cables under normal operating conditions. The essential requirement for the fireproofing of leadsheathed paper-impregnated cables is that the fireproofing should be sufficiently heat-resisting fully to protect the cable, of sufficiently low thermal conductivity so as not to decrease unduly the current rating of the cable, and that either its composition is such that it does not set up corrosion of the lead sheath or, alternatively, that it is provided with protection against such corrosion.

A combination of all these properties was not easy to find, and a good deal of investigation was required before the best materials were found. Also in some cases the use of the best method was not possible on systems already installed, and alternative methods had to be sought. Dealing with the question of cables emerging from the floor and going upwards to connect to switchgear, etc., or to other cables run in the vicinity of such gear, etc., the method selected for new installations and for existing installations where space was available was to use moulded asbestos supplied by the makers in the form of split-tubes which could be clamped around the exposed length of the cable. Apart from the ease of fitting and the comparatively pleasing finish of the work, this material represents the nearest approach to the ideal characteristics mentioned above. Magnesia has probably a higher degree of resistance to fire than the asbestos mouldings, but the thermal resistivity of the material is so high that the current rating of the cable would be greatly diminished.

The thermal resistivity of moulded asbestos is of the order of 700 thermal ohms, a value which with the thickness of material used would normally decrease the current rating of the cables by about 20 per cent. Against this, however, may be offset the normal increase of rating due to the fact that the cables to the ground are probably grouped, whereas when they are taken to switchgear they are separated apart a distance sufficient to free them from 'proximity heating'. This generalization, however, must not be carried too far, since if the cables in the run are separated throughout and operated at or near their maximum current, the asbestos-covered section would reduce the permissible current to an extent which would require serious consideration.

The fire-resisting properties of the moulded asbestos material appear to be extremely good. From figures quoted by the makers, the white asbestos material only begins to suffer damage when subjected to a temperature of $2,500^{\circ} \mathrm{F}$., and the asbestos compound can withstand much higher temperatures for short periods. Tests carried out by the F.R.A. on cables protected by moulded asbestos exposed to a serious oil fire showed that, while parts of the burning enclosure reached a temperature of about $1,100^{\circ} \mathrm{F}$., the highest recorded temperature on the protected cable sheath was $176^{\circ} \mathrm{F}$. More severe tests of the same material used as a protective covering for steel girders showed that after a period of more than four hours exposure, during which the ambient temperature rose to $2,100^{\circ} \mathrm{F}$., the temperature of the protected ironwork was only $850^{\circ} \mathrm{F}$. It should be noted that the material is somewhat alkaline and that, to ensure protection against corrosion, the lead sheath of the cable should first be protected with a layer of bitumen paint and wrapped with one layer of bituminized tape.

For existing installations in which the conditions of erection are such as not to allow the use of moulded asbestos, a very good degree of fire resistance can be ensured by stripping off all the existing protective 
wrappings to the armour (or lead as the case may be), painting the cable with bitumen paint, wrapping with a layer of bituminized tape and then applying two layers of asbestos tape with a sensible overlap. The asbestos should be freely painted with silica paint.

For a number of years the research staffs of the associated firms of cable makers have been attempting to produce fire-resisting or self-extinguishing rubber compounds, and a fair degree of success has been obtained in imparting these properties to rubber. The fundamental difficulty has been that raw rubber is not self-extinguishing when once ignited, and the other materials which it is necessary to incorporate in the 'mix' to overcome the lack of self-extinguishing properties greatly modify its other desirable properties.

A new synthetic material has been discovered which belongs to the same general chemical group as rubber. This material in its raw state is very similar in its physical properties to raw rubber. It is converted into a suitable 'mix'. As, however, the material is fire-resisting, it is not necessary to obtain the fire resistance at the expense of other properties.
Extensive tests have shown that this synthetic material is more resistant than rubber to deleterious influences.

Fires which have occurred in coal mines during recent years with deplorable loss of life raised the question in some minds as to how far electrical cables have been responsible for either initiating a fire or conveying an existing fire from one part of a mine to another. At the instigation of Mr. Horsley, electrical inspector of mines, the cable makers agreed to carry out experiments with the view of obtaining data which would answer certain specific questions. It was found that the application of a hot external flame for about 15 seconds was necessary to ignite the compound on the wrappings of a standard C.M.A. cable; hence it does not seem probable that such wrappings around the cable would be ignited as the result of a transient flame such as would arise, for example, from an explosion of fire damp. The experiments also showed that the armour wires practically completely protected the inside of the cable. The cable makers have to be congratulated on the way they have co-operated in very expensive researches for their mutual benefit.

\title{
NEW INTERNATIONAL COMMISSION OF SNOW AND GLACIERS
}

\author{
By F. E. Matthes
}

\begin{abstract}
A T the Seventh Assembly of the International Union of Geodesy and Geophysics, which was held in Washington last September, the International Association of Scientific Hydrology, one of the component units of the Union, effected the consolidation of two of its own commissions--the Commission of Snow and the Commission of Glaciers. The action was taken after a preliminary poll of the membership of the two commissions had shown an overwhelming majority in favour of the consolidation. Moreover, the presidents of both commissions, Prof. J. E. Church, of the University of Nevada, U.S.A. (snow), and Mr. J. M. Wordie, of St. John's College, Cambridge, Britain (glaciers), had strongly recommended it.

Prof. Church was designated acting president of the new Commission of Snow and Glaciers, to serve in that capacity until international relations will permit the holding of a formal election of officers. Like all other sections of the International Union of Geodesy and Geophysies, the Association of Hydrology has deferred election of officers for the present triennial period, in view of the sparse attendance of European delegates at the Washington assembly, due to war conditions.

The new Commission of Snow and Glaciers aims at taking into its purview all research relating to snow and ice in their varied forms. It might appropriately have been named Commission of Snow and Ice, but it preferred to adopt the name Commission of Snow and Glaciers in deference to the former Commission of Glaciers, which is by far the older of the two bodies that are now consolidated, and which, indeed, was in existence long before the Association of Hydrology was formed.
\end{abstract}

The original Commission Internationale des Glaciers had its inception in 1894, at the International Geological Congress at Zurich. It was charged, broadly, with the task of studying existing glaciers throughout the world; but actually its efforts have been concentrated on securing statistics of the secular variations-advance and recession-of glaciers in response to climatic fluctuations. Inasmuch as this task requires the making of annual measurements on large numbers of glaciers in different countries, with the aid of co-operating agencies, governmental, scientific, and other, it has inevitably grown into a vast enterprise. The results, however, have proved of value, not only to glaciologists but also to hydrologists, hydraulic engineers (making use of run-off from glaciers for economic purposes), and climatologists.

In 1914 the work of the Commission was stopped by the war, and co-ordinated effort ceased for a number of years. In 1927, however, at the invitation of the International Association of Scientific Hydro$\log y$, the Commission transferred its functions and its personnel to a new Commission Glaciologique created by the Association, and under these new auspices its work has been carried on ever since.

Meanwhile, at the Lisbon assembly, in 1933, the Association set up a Commission of Snow and appointed Prof. Church president of it. So rapidly did this Commission grow under the enthusiastic leadership of its president that by 1936, when the Association met in Edinburgh, it had become by far the largest and most active of all the commissions of the Association and had extended its field to cover all phenomena of snow and ice, with the exception of glacier variations. Overlap with the work of the Commission of Glaciers seemed almost inevitable, 